\title{
DE BETEKENIS VAN DE UITSPRAKEN VAN DE ONDERNEMINGSKAMER
}

\author{
door Prof. Dr. A. Th. de Lange
}

Een uitspraak van de Ondernemingskamer (O.K.) van het Gerechtshof te Amsterdam aangaande een jaarrekening van een rechtspersoon komt tot stand, indien een belanghebbende van oordeel is, dat de jaarrekening niet beantwoordt aan hetgeen daaromtrent in de wet is bepaald en op grond daarvan in rechte van de rechtspersoon vordert haar jaarrekening in te richten overeenkomstig bij rech. terlijk bevel te geven aanwijzingen. De procureur.generaal bij het Gerechtshof te Amsterdam is eveneens bevoegd, in het openbaar belang, een rechtsvordering met gelijke strekking in te stellen. Tot nu toe heeft het O.M. geen gebruik gemaakt van deze bevoegdheid. De zaak wordt met gesloten deuren behandeld; het arrest wordt echter in het openbaar uitgesproken. De O.K. kan in haar uitspraak hetzij de vaststelling of goedkeuring van de jaarrekening vernietigen en aan de bestuurders van de rechtspersoon bevelen binnen een bepaalde termijn een nieu we jaarrekening op te maken met in achtneming van de in het arrest vermelde aanwijzingen, hetzij volstaan met het bevel bij het opmaken van toekomstige jaar. rekeningen bepaalde aanwijzingen in acht te nemen, hetzij de vordering (even tueel reeds op grond van haar bevindingen dat de eiser geen belanghebbende bij de jaarrekening is) geheel afwijzen, resp. niet ontvankelijk verklaren.

De bedoelde rechtsvordering wordt ingesteld bij dagvaarding, welke vermeldt in welk opzicht de jaarrekening naar het oordeel van de eiser herziening behoeft. Mede door de omstandigheid, dat de Wet op de Jaarrekening van ondernemin gen op 1 mei 1971 in werking is getreden en dat de eerste dagvaarding in een jaarrekeningzaak eerst op 18 september 1975 is betekend, zijn tot nu toe nog slechts zeven eindarresten in jaarrekeningzaken door de O.K. gewezen. De thans voorhanden uitspraken zijn nog slechts van beperkte betekenis voor het leren kennen van de inzichten van de O.K. ten aanzien van de nakoming van de wet. telijke bepalingen omtrent de jaarrekening. Die betekenis beperkt zich tot de rechterlijke uitspraken aangaande de door belanghebbenden aan de orde gestelde geschilpunten omtrent de interpretatie der wet op bepaalde concrete punten ten aanzien van een betrekkelijk klein aantal jaarrekeningen.

In dit verband is de keuze van de wetgever met betrekking tot het systeem der wetgeving van bijzonder belang. In titel 6 van Boek 2 B.W., handelende over de jaarrekening, worden onderscheiden:

Afdeling 1: Algemene bepalingen

Afdeling 2: Nadere bepalingen omtrent de balans en de toelichting

Afdeling 3: Nadere bepalingen omtrent de winst- en verliesrekening en de toe. lichting.

Met betrekking tot deze indeling valt uit art. 310 af te leiden dat de beide afdelingen 2 en 3 het karakter van minimum voorschriften dragen; het zal van de omstandigheden in elke onderneming afhangen of krachtens de artikelen 308 en 
309 nog meer gegevens en toelichtingen moeten worden verstrekt dan die welke de twee afdelingen verlangen.

De essentie van de wet, neergelegd in afdeling 1 , kan in de volgende 5 punten worden samengevat:

$a$. de jaarrekening geeft een zodanig inzicht dat een verantwoord oordeel kan worden gevormd omtrent het vermogen en het resultaat van de rechtsper. soon, alsmede omtrent haar solvabiliteit en liquiditeit (art. 308);

$b$. de weergave van vermogen en resultaat dient getrouw en stelselmatig te zijn (art. 309);

c. de grondslagen waarop de waardering van de activa en de passiva en de be. paling van het resultaat berusten, voldoen aan normen die in het maatschappelijk verkeer als aanvaardbaar worden beschouwd (art. 311, lid 1);

d. de toelichting als bijlage bij de balans, resp. de winst- en verliesrekening, geeft een uiteenzetting omtrent de grondslagen van waardering en resultaatbepaling (art. 311, lid 2);

$e$. een wijziging in de grondslagen wordt, indien zij van wezenlijk belang is, uit. drukkelijk vermeld, onder mededeling van haar invloed op het vermogen en het resultaat (art. 311, lid 3).

De bestuurder van de rechtspersoon vindt nauwelijks enig voorschrift dat aan de onderneming een bepaalde handelwijze, anders dan het verstrekken van bepaal. de specificaties en informatie, voorschrijft. Aan de rechtspersoon wordt ten aan. zien van de grondslagen van balanswaardering en resultaatbepaling een binnen bepaalde grenzen gehouden vrije keuze gelaten, mits zij de inhoud van die keuze in de jaarrekening uiteenzet. Het zou echter onjuist zijn te menen, dat de wet een duidelijke leidraad biedt voor de beoordeling van de aanvaardbaarheid van een jaarrekening.

De wetgever heeft het gebrek van het bestaan van de leemten, die de vage bewoordingen van de wet hebben opengelaten, echter doelbewust aanvaard. Hij heeft de gedachte om bij algemene maatregel van bestuur nadere regels te stellen omtrent de toelaatbaarheid van bepaalde maatstaven van waardering uitdrukkelijk verworpen. Het gevaar van verstarring wanneer men de wet nader zou gaan invullen werd zwaarder gewogen dan het voordeel van het doorhakken van knopen ter bevordering van uniformiteit die de doorzichtigheid van de jaarrekening beoogt te vergroten. Maatschappelijke ontwikkelingen dienen zich in de opvat. ting van de wetgever soepel te kunnen voltrekken. De rechtsvorming op dit gebied is door de wetgever aan de rechter overgelaten.

Hoezeer men met de gedachtengang van de wetgever kan instemmen, het betekent wel, dat het bestuur van de rechtspersoon zijn standpunt aangaande de aanvaardbaarheid van bepaalde stelsels en grondslagen van waardering en resul. taatbepaling in hoge mate op eigen oordeelsvorming zal moeten baseren. Het is zijn op bedrijfseconomische deskundigheid gebaseerde persoonlijk inzicht, zo nodig aangevuld met de adviezen van de controlerend accountant, dat hem de weg naar het juiste standpunt ten opzichte van te kiezen grondslagen en stelsels zal moeten wijzen.

Tevens zal de rechtspersoon te rade kunnen gaan bij de „Beschouwingen naar aanleiding van de Wet op de Jaarrekening van ondernemingen", samengesteld door en onder verantwoordelijkheid van de Commissies Jaarverslaggeving van de Raad van Nederlandse Werkgeversverbonden, de Federatie Nederlandse Vak. 
beweging, het Christelijk Nationaal Vakverbond en het Nederlands Instituut van Registeraccountants. Met betrekking tot de inhoud van deze Beschouwingen en de plaats welke deze innemen in het geheel van kennisbronnen, waarover de besturen der rechtspersonen kunnen beschikken wordt verwezen naar het artikel van de heer Drs. Mr. H. Beckman onder de titel „Het Tripartiete Overleg en jaarverslaggeving".

Hoewel, zoals hiervoren reeds is gesteld, het terrein van de uitspraken van de O.K. zich niet verder uitstrekt dan tot de door belanghebbenden aan de orde ge. stelde geschilpunten omtrent de interpretatie der wet op bepaalde concrete pun. ten, geven de arresten van de O.K. niettemin gelegenheid zich een oordeel te vormen omtrent de opvatting van de O.K. ten aanzien van hiervoren vermelde al. gemene regels, voor zover deze opvatting althans uit de gepubliceerde arresten kan worden afgeleid. In verband daarmede volgen hieronder ter illustratie enkele algemene uitspraken van de O.K. met betrekking tot essentiële punten $\left.{ }^{1}\right)$. De te vermelden uitspraken hebben met name betrekking op de omstandigheid, dat de wetgever, zoals uit de hiervoren genoemde 5 punten blijkt, de besturen der rechts. personen in hoge mate heeft vrijgelaten in de keuze van de grondslagen van ver. mogens- en resultaatbepaling, welke zij voor haar onderneming als meest verkies lijk beschouwen, mits deze de toepassing van de in de 5 punten geschreven grond. gedachten in acht neemt.

In het stelsel der wet is het begrijpelijk, dat de grondslagen bedoeld in art. 311 , uit de jaarrekening moeten blijken. De O.K. heeft dan ook meer dan eens geoor. deeld, dat de jaarrekening een uiteenzetting omtrent de bedoelde grondslagen moet geven. Het hierna volgende citaat maakt deel uit zowel van het arrest Douwe Egberts (DE) als van het arrest Koninklijke Scholten-Honig (KSH): „De O.K. acht de voorgeschreven uiteenzetting van de toegepaste grondslagen van essentieel belang voor het inzicht dat de jaarrekening ingevolge art. 2 WJO dient te geven. Omtrent de vraag, welke grondslagen zijn toegepast, mag geen misverstand ontstaan en de toelichting dient daarop een duidelijk antwoord te geven. De wet eist dan ook niet slechts een (blote) vermelding van de toegepaste grondslagen, doch een uiteenzetting daarvan". In het arrest DE is hieraan nog de zin toegevoegd: „Daarnaast acht de O.K. tevens van essentieel belang dat de eenmaal gekozen grondslagen stelselmatig in volgende jaren worden toegepast", terwijl in het ar. rest KSH een iets anders geformuleerde zin met gelijke strekking is opgenomen.

In het systeem der wet waarin alles aankomt op de keuze van en de uiteen zetting omtrent de grondslagen van waardering en resultaatbepaling, is het be grijpelijk dat de O.K. een sterke nadruk legt op de beoordeling van de toelichting, met name ten aanzien van de uiteenzetting der gehanteerde grondslagen. De les uit de geciteerde arresten, maar ook uit andere arresten van de O.K. is, dat de rechtspersoon slechts dan op dit punt de instemming van de O.K. met de toepas. sing van de wet kan verwerven, indien de toelichting ten minste een volledige en duidelijke beschrijving van de voor de vermogens. en resultaatbepaling rele. vante factoren vermeldt, waardoor het de lezer duidelijk wordt, welke begrippen vermogen en resultaat in het concrete geval van de betreffende jaarrekening door de rechtspersoon zijn gehanteerd en welke betekenis mitsdien aan het getoonde resultaat en vermogen moet worden toegekend.

\footnotetext{
If Een uitgebreid overzicht van de jurisprudentie van de O.K. vindt men in het artikel van Mr. Th. S. IJsselmuiden in "De Naamloze Vennootschap" van januari/februari 1979, getiteld: "Jurisprudentie van de Ondernemingskamer".
} 
De aanwijzingen in de arresten worden uiteraard in hoge mate door de omstandigheden in het concrete geval bepaald, reden waarom men zich moet hoe. den voor een te slaafse navolging van die aanwijzingen in andere omstandighe. den. Veeleer dient de rechtspersoon zich te (her)bezinnen op de vraag of de jaarrekening aan de gestelde, hiervoren in algemene zin geformuleerde, eisen voldoet dan wel de uiteenzetting omtrent de keuze der grondslagen verbetering be. hoeft.

Indien het bestuur van de rechtspersoon tot het oordeel komt, dat met de ver. betering van de uiteenzetting niet kan worden volstaan, maar dat de grondslagen zelf dienen te worden herzien, zal het rekening moeten houden met de omstandigheid, dat ook de nieuwe grondslagen aanvaardbaar moeten zijn. Zo besliste de O.K. in het arrest Vulcaansoord: „De vraag of Vulcaansoord op dit nieuwe sys. teem had mogen overgaan beantwoordt de O.K. ontkennend. Weliswaar is de verplichting van Vulcaansoord uit hoofde van de voor haar werknemers getrof. fen pensioenregeling beperkt ..., doch zulks neemt niet weg dat er een backservice-verplichting is en dat Vulcaansoord verplicht is daarvan haar deel te betalen. Aangezien deze backservice-verplichting en het deel van Vulcaansoord daarin omvangrijk zijn en bovendien in een tijd van inflatie snel in omvang kunnen toe. nemen, is het voor het inzicht dat de jaarrekening ingevolge het bepaalde in ar. tikel 2 WJO dient te geven noodzakelijk, dat Vulcaansoord de contante waarde van haar deel in de backservice-verplichting in haar jaarrekening vermeldt. Hier. aan doet niet af dat de verplichting tot premiebetaling voor Vulcaansoord vervalt indien zij geen werknemers meer in dienst heeft. Bij de onderhavige jaarrekening wordt er immers van uitgegaan dat de onderneming in de bestaande omvang wordt gecontinueerd. Van deze vooropstelling van continuitteit dient ook bij het vaststellen van de betekenis van de backservice-verplichting te worden uitgegaan. Het nieuwe systeem van Vulcaansoord, waarin vermelding van bedoelde contante waarde achterwege blijft, dient mitsdien te worden verworpen."

Het ligt in de lijn van de uitspraken van de O.K. dat de redenen die tot wijziging van de keuze der grondslagen hebben geleid, in de jaarrekening dienen te worden vermeld. In het arrest KSH vindt men de volgende uitspraak: „Aangezien voor een onderneming als KSH gegronde redenen aanwezig kunnen zijn geweest de hier bedoelde stelselwijziging - ertoe strekkende, dat de stijgingen van historische aankoopprijzen of marktprijzen ten opzichte van die prijzen op de vorige balans niet langer in mindering op de winst gebracht worden - in te voeren, be. hoeft deze stelselwijziging niet onaanvaardbaar te zijn. KSH dient echter alsnog de redenen die tot deze stelselwijziging hebben geleid, in de jaarrekening te vermelden". In dit verband is ook de volgende uitspraak van de O.K. van belang: „Voorts dient de vraag of een stelselwijziging aanvaardbaar is, beoordeeld te wor. den naar het inzicht dat een jaarrekening in haar geheel, mede in het licht van recente voorafgaande jaarrekeningen, dient te geven. Derhalve mag in een jaar. rekening niet worden volstaan met de invloed van iedere stelselwijziging, indien deze op zichzelf van wezenlijk belang is, op het vermogen en het resultaat afzon. derlijk te vermelden, doch dient tevens de totale invloed van alle wijzigingen, indien zij tezamen van wezenlijk belang zijn, te worden vermeld."

Hoewel de formulering van de hierna volgende uitspraak een grotere reikwijd. te doet vermoeden, wordt de algemene geldigheid van de uitspraak toch beperkt door de omstandigheden van het concrete geval. Het volgende citaat is ontleend 
aan het arrest KSH: „KSH heeft in voorgaande jaren, voor zover de waardering van de voorraden tegen hogere prijzen geschiedde dan een jaar tevoren, dit verschil steeds als prijsverschillenreserve toegevoegd aan het eigen vermogen onder de post: Vermogensverschillen door herwaardering. $\mathrm{Zij}$ heeft van deze prijsver. schillenreserve een bedrag van $f 15,9$ miljoen in mindering op genoemde post en ten gunste van de winst- en verliesrekening gebracht. Dit laatste is niet juist, aangezien het voor het inzicht, dat de jaarrekening dient te geven niet aanvaard. baar is, dat het vroeger reeds onder het eigen vermogen verantwoorde bedrag van $f$ 15,9 miljoen thans als winst wordt verantwoord." Hieruit kan worden geconcludeerd, dat eenmaal getoond eigen vermogen niet op een later tijdstip als winst kan worden opgevoerd.

De plaats voor de uiteenzetting omtrent grondslagen van waardering en resul. taatbepaling is de toelichting in de jaarrekening en niet het jaarverslag. Citaat ar. rest Pakhoed: „De jaarrekening dient als één geheel te worden opgemaakt, vastgesteld en goedgekeurd. De wettelijke eis dat de jaarrekening het beoogde inzicht dient te geven brengt met zich dat dit inzicht uitsluitend door kennisneming van de jaarrekening zelf gevormd moet kunnen worden. Een eventuele verwijzing in de jaarrekening naar een bepaalde passage in het jaarverslag van de directie heeft niet tot gevolg dat deze passage als deel van de jaarrekening kan worden be schouwd."

Tenslotte moge erop worden gewezen, dat indien rekening wordt gehouden met de mogelijkheid dat krachtens de artikelen 308 en 309 boek 2 BW nog meer gegevens en toelichtingen (moeten) worden verstrekt dan die welke de afdelingen 2 en 3 van titel 6 verlangen (zoals hiervoren uiteengezet), men niet uit het oog mag verliezen, dat die toelichtingen dan deel uitmaken van de jaarrekening en dus moeten leiden tot verbetering van het inzicht. Zie arrest DE: „Indien de HBM deel uitmaakt van de jaarrekening dienen verschillen in de presentatie met elders in de jaarrekening vermelde gegevens te worden toegelicht". 